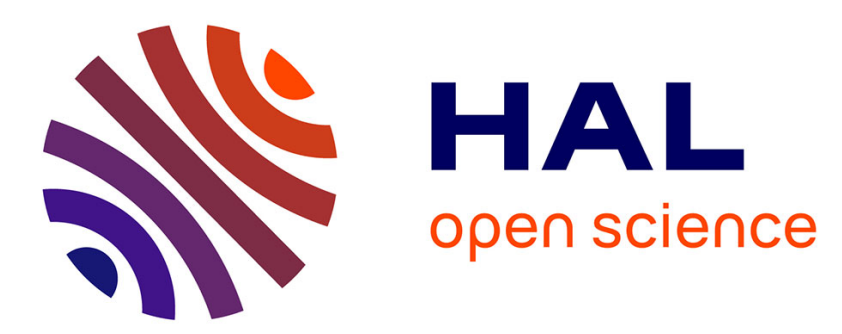

\title{
Phytoremediation of organic pollutants using mycorrhizal plants: a new aspect of rhizosphere interactions
}

\author{
Erik Joner, Corinne Leyval
}

\section{- To cite this version:}

Erik Joner, Corinne Leyval. Phytoremediation of organic pollutants using mycorrhizal plants: a new aspect of rhizosphere interactions. Agronomie, 2003, 23 (5-6), pp.495-502. 10.1051/agro:2003021 . hal-00886202

\section{HAL Id: hal-00886202 https://hal.science/hal-00886202}

Submitted on 1 Jan 2003

HAL is a multi-disciplinary open access archive for the deposit and dissemination of scientific research documents, whether they are published or not. The documents may come from teaching and research institutions in France or abroad, or from public or private research centers.
L'archive ouverte pluridisciplinaire HAL, est destinée au dépôt et à la diffusion de documents scientifiques de niveau recherche, publiés ou non, émanant des établissements d'enseignement et de recherche français ou étrangers, des laboratoires publics ou privés. 


\title{
Phytoremediation of organic pollutants using mycorrhizal plants: a new aspect of rhizosphere interactions
}

\author{
Erik Jautris JONER*, Corinne LEYVAL \\ Laboratoire des Interactions Microorganismes-Minéraux-Matière Organique dans les Sols (LIMOS), CNRS UMR 7137, Faculté des Sciences, \\ Université Henri Poincaré, Nancy 1, BP 239, 54506 Vandœuvre-lès-Nancy Cedex, France
}

(Received 7 October 2002; accepted 25 March 2003)

\begin{abstract}
Phytoremediation as a means of cleaning up polluted soils has gained popularity during the last decade due to its convenience and low costs of installation and maintenance. When the target pollutant is biodegradable, this technology exploits the stimulating effect that roots have on microbial processes and physical/chemical modifications in the rhizosphere. Among the microorganisms that affect rhizosphere processes, symbiotic fungi forming mycorrhizas induce a series of changes in plant physiology, nutrient availability and microbial composition that may determine the outcome of a phytoremediation attempt. Beyond the rhizosphere, mycorrhizal hyphae act as the roots of the roots, and may thus extend the rhizosphere into the bulk soil by creating a new interface of soil-plant interactions: the hyphosphere. We here discuss some of the recent results on phytoremediation of organic pollutants with emphasis on processes in the mycorrhizosphere, and highlight future research priorities.
\end{abstract}

arbuscular mycorrhiza / bioremediation / polycyclic aromatic hydrocarbons / root exudation

Résumé - La phytoremédiation de polluants organiques utilisant des plantes mycorhizées : un nouveau champ d'étude pour les interactions de la rhizosphère. La phytoremédiation est une technique de traitement des sols pollués qui attire beaucoup d'attention depuis une dizaine d'années en raison de la facilité et du faible coût d'installation et de maintenance. Quand le polluant ciblé est biodégradable, cette méthode utilise les racines pour stimuler l'activité microbienne et modifier les propriétés physico-chimiques dans la rhizosphère. Parmi les microorganismes qui influencent les processus rhizosphériques, les champignons mycorhiziens formant des mycorhizes induisent un certain nombre de changements dans la physiologie des plantes, la disponibilité des nutriments, la composition des communautés microbiennes, qui peuvent aussi influencer la phytoremédiation. Au-delà de la rhizosphère, les hyphes de champignons mycorhiziens agissent comme les racines des plantes, et prolongent ainsi l'étendue de la rhizosphère en créant une nouvelle interface entre la plante et le sol : l'hyphosphère. Des résultats récents sur la phytoremédiation de polluants organiques sont discutés ici, et des hypothèses sur les mécanismes impliqués et les priorités pour les recherches futures dans ce domaine sont présentées.

mycorhizes à arbuscules / bioremédiation / hydrocarbures aromatiques polycycliques / exudation racinaire

\section{INTRODUCTION}

\subsection{Phytoremediation}

Phytoremediation refers to the use of plants to clean up contaminated soils. In the case of non-degradable pollutants such as heavy metals and metalloids, the precise terms covering the involved aspects of phytoremediation are rhizofiltration (metals in water), phytoextraction (metals in soil), phytovolatilization (metals that may be volatilized: e.g. Se and $\mathrm{Hg}$ ) and phytostabilization (control of spread by erosion or leaching). When organic, biodegradable pollutants are the target, phytoremediation may comprise rhizodegradation (microbial degradation in the rhizosphere), phytodegradation (degradation of compounds absorbed by the plant), and hydraulic control (limiting the spread of a plume in soil by plant evapotranspiration) [20, 23]. Here we will mainly consider different aspects of rhizodegradation.

Communicated by Philippe Hinsinger (Montpellier, France)

* Correspondence and reprints

Erik.Joner@skogforsk.no

Present adress: Norwegian Forest Research Institute, Högskoleveien 12, 1432 Aas, Norway. 


\subsection{Organic pollutants}

Apart from being more or less degradable, organic pollutants (Fig. 1) have other important characteristics that vary greatly between compounds, notably electrochemical charge and solubility. Non-polar compounds, such as hydrocarbons, are thus poorly soluble in water and sorb readily to hydrophobic soil constituents like soil organic matter. Polar compounds, such as some halogenated organics, many pesticides and explosives are more soluble, but not necessarily more mobile in soil due to adsorption to various charged surfaces [46].

The manner by which organic pollutants are introduced to soil may vary from diffuse atmospheric depositions to intended application and spills. The resulting concentrations may thus vary greatly, a factor that, together with contact time, has a strong influence on bioavailability and toxicity [59, 70]. A particular effect of the contact time between soil and a range of organic pollutants is that many compounds are rendered more strongly sequestered and less bioavailable with time. This phenomenon, known as aging, strongly affects the feasibility and success of soil remediation [27].

\subsection{Mycorrhizas}

Mycorrhizas are ubiquitous root-fungus symbioses that comprise three major groups: ectomycorrhizas (ECM: formed mainly by forest trees), ericoid mycorrhizas (formed by heather plants like the Ericaceae) and arbuscular mycorrhizas (AM: formed mainly by herbaceous plants) [68]. The two latter groups are endomycorrhizas, as they enter into root cells during colonization, as opposed to ectomycorrhizas in which the fungi merely envelop the epidermis and, partially, the cortex cells of the root.

The major function of mycorrhizas is nutrient transport. Extra-radical hyphae anchored in the root thus exploit soil outside the root where it absorbs mineral nutrients (mainly $\mathrm{N}, \mathrm{P}$ and micronutrients), translocate them back to the root, and transfer them to the host plant in exchange for phytosynthetically fixed $\mathrm{C}$ in the form of sugars. The fact that these hyphae are fed with $\mathrm{C}$ and energy from the host plant gives them an advantage over other microorganisms with respect to growth and active metabolism in nutrient-poor substrates. In a biodegradation context, it is important to note that the three groups of mycorrhiza have very different saprophytic capacities. The ericoid mycorrhizal fungi are potent degraders, ECM fungi are moderately capable, while AM fungi are obligate symbionts with little or no capacity for degradation of organic materials $[50,51]$. All groups of mycorrhiza do, however, interact with and modify the microbial communities that the hyphae encounter in soil (see below), and in this manner they may all affect microbial degradation processes indirectly.

\section{EXPERIMENTAL EVIDENCE}

\subsection{Rhizosphere effects}

Successful phytoremediation (rhizodegradation) of organic pollutants has been demonstrated for a wide range of compounds or compound mixtures, such as aliphatic

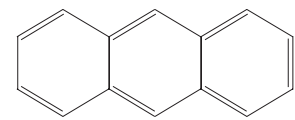

Anthracene
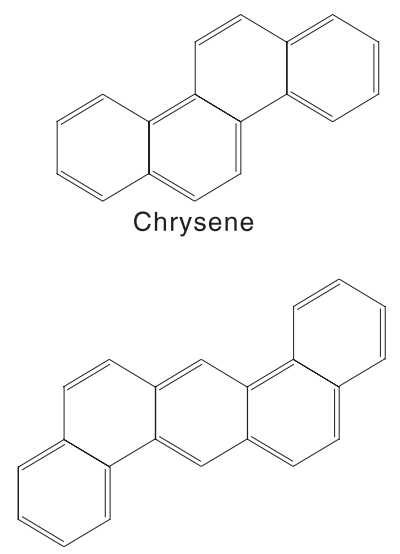

Dibenz(a,h)anthracene<smiles>ClC=C(Cl)Cl</smiles>

Trichloroethylene

(TCE; dry-cleaning agent)

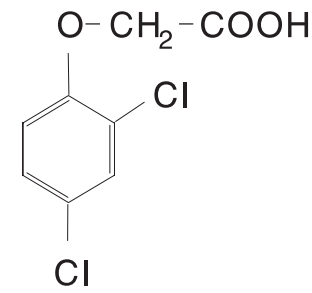

2,4-dichlorophenoxyacetic acid (2,4-D; herbicide)<smiles>Cc1c([N+](=O)[O-])cc([N+](=O)[O-])cc1[N+](=O)[O-]</smiles>

2,4,6-trinitrotoluene (TNT; explosive)

Figure 1. Examples of some organic pollutants for which the feasibility of phytoremediation has been verified.

hydrocarbons [11, 26], fuel oil and other mixed petroleum hydrocarbons $[10,53,71]$, polycyclic aromatic hydrocarbons (PAHs) [58, 65], explosives [67, 75], pesticides [31] and chlorinated organics $[2,66]$. 
The mechanisms behind enhanced degradation in the rhizosphere are not known, and mechanistic explanations are probably as complex as the environment in which they take place. Putative explanations include direct effects of root-derived enzymes [25], and indirect effects of enhanced aeration due to root burrowing and water consumption, enhanced microbial activity and modified microbial composition due to $\mathrm{C}$ input from root exudates, priming or triggering effects of metabolic precursors exuded by roots (e.g. phenolics) that induce enzymatic activity/metabolic pathways that may attack the pollutant, and unspecific effects of changes in $\mathrm{pH}$, osmotic potential, red-ox potential, partial pressures of $\mathrm{O}_{2} / \mathrm{CO}_{2}$, etc. [15] Enhanced microbial activity is probably a key component in rhizodegradation. However, the modified conditions for microbial growth in the rhizosphere do not proportionally increase the biomass of all its organisms, but rather change the community composition $[47,69]$, thus altering the rhizosphere with respect to its metabolic capacities [19]. Similar changes are observed when soil is contaminated with organic pollutants [74], and typically the proportion of compatible degraders increases after a certain lag period, the length of which depends on the complexity and recalcitrance of the introduced pollutant [43]. Changes in microbial populations of a polluted soil following input of root exudates has in some cases selectively increased the proportion of pollutant degraders in the sense that the number of organisms that can grow on the pollutant as sole source of $\mathrm{C}$ and energy is enhanced [52]. It is, however, more commonly observed that the proportion of pollutant degraders remain unchanged in polluted soil receiving root exudates, even when degradation is enhanced [22, 35]. The addition of mineral nutrients may, on the other hand, specifically favor pollutant degraders, particularly in nutrientpoor soil where the pollutant is degradable by direct microbial metabolism and present in large amounts, thus contributing to increased soil C/N and C/P ratios [42, 45].

In many cases degradation is not mediated by direct metabolism, but rather by co-metabolism [30], partially rendering enumeration of pollutant degraders irrelevant. Good methods for distinguishing co-metabolism from diauxic growth and direct metabolism in soil are lacking, but for certain compounds, the former is the only way of degradation, as no organisms are known that may degrade them directly. However, the exploitation of co-metabolic processes may also be a pitfall, as the input of readily degradable $\mathrm{C}$ can in some cases reduce the mineralization of the organic pollutant, due to the fact that degrader organisms prefer the more readily degradable substrate rather than the pollutant $[1,9,72]$.

The rhizosphere is not only enriched with readily degradable $\mathrm{C}$, it is also frequently deficient in mineral nutrients due to root absorption and slow diffusion of certain nutrients such as $\mathrm{NH}_{4}$ and $\mathrm{PO}_{4}$ towards the root surface [37, 54]. Many soils polluted with organics contain organic matter with high $\mathrm{C} / \mathrm{N}$ ratios, which partially explains why biodegradation responds positively to $\mathrm{N}$ additions $[8,72,77]$. As plants compete successfully for soil inorganic $\mathrm{N}[38,78]$, microbial degradation in rhizosphere soil will to some extent suffer from a lack of mineral nutrients. Yet, enhanced degradation rates may be observed, possibly in defined zones where the combination of chemical parameters is optimal: carbon and energy from root deposits are available, but the level of inorganic nutrients is

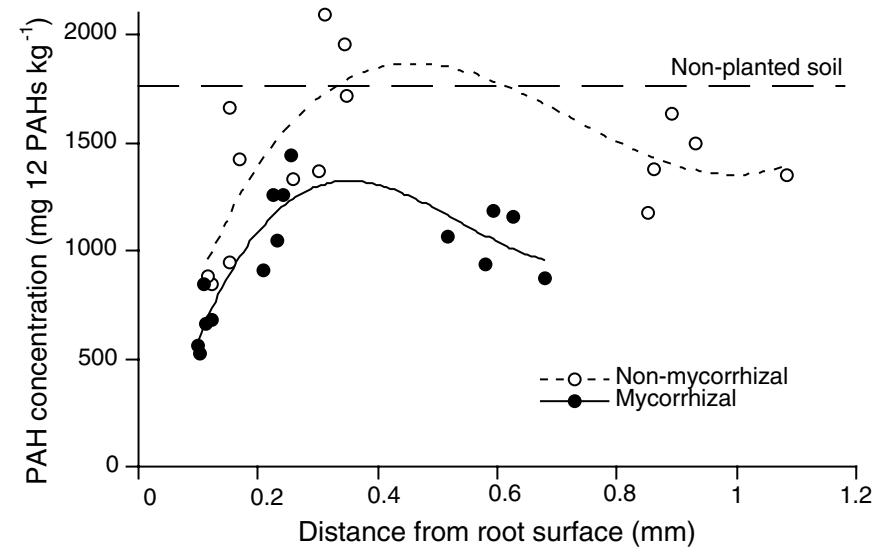

Figure 2. Rhizosphere gradients of PAH dissipation (sum of the concentrations of 12 priority PAHs) measured in an industrially polluted soil in the presence and absence of arbuscular mycorrhiza (redrawn from data in [36].

not decreased to levels that impede microbial activity. In a recent study with PAH rhizodegradation in two industrially polluted soils planted with clover and ryegrass [36], the highest pollutant dissipation* was observed in the soil in the inner rhizosphere $(<0.2 \mathrm{~mm}$ from the root surface), with little or no effect remaining at a distance of $>1 \mathrm{~mm}$ (Fig. 2). As this experiment lasted for 6 months, effects of irreversible sorption on senescent roots and cell debris may have been as important for PAH dissipation as degradation, particularly for soil in the inner rhizosphere (Fig. 3a). At a distance of ca. $0.3-0.6 \mathrm{~mm}$ from the surface of the roots, we observed no additional PAH dissipation compared with unplanted soil. This may be due to a lower amount of root debris involved in adsorption and a severe depletion of mineral nutrients at this location (Fig. 3b). Further away from the surface of the roots (ca. $0.6-1.5 \mathrm{~mm}$ ), PAH levels were again reduced. Here, degradation may have been enhanced, as both mineral nutrients and probably $\mathrm{O}_{2}$ concentrations were higher than closer to the roots, while root exudation still provided an input of $\mathrm{C}$.

The soils used in this experiment were either highly organic (38\% organic matter) or rich in clay and carbonate (30\% and $23 \%$, respectively). Less extreme soils with coarser texture may of course have wider rhizodegradation zones and behave differently with respect to irreversible PAH adsorption. In sand, the effect of ryegrass roots on microbial growth and phenanthrene (a 3-ring PAH) degradation was observed up to $9 \mathrm{~mm}$ from the surface of the roots [12].

\footnotetext{
The term 'dissipation' is more correct than 'degradation' when the mechanism responsible for reduced concentration of the parent compound is unknown. Dissipation comprises one or more of the following processes: complete or partial biodegradation (i.e. mineralization or biotransformation), sorption/polymerization, volatilization, photo-oxidation, and transport loss by dispersion, leaching, plant uptake, etc. Under controlled conditions where only non-volatile compounds are considered and no chemical oxidizing agents $\left(\right.$ e.g. $\mathrm{O}_{3}$ ) or thermal treatments are imposed, degradation and sorption are the only significant components of dissipation. For easily degradable compounds (e.g. low molecular weight PAHs), degradation is largely dominant, while for more recalcitrant molecules (e.g. high molecular weight PAHs), sorption may contribute significantly.
} 


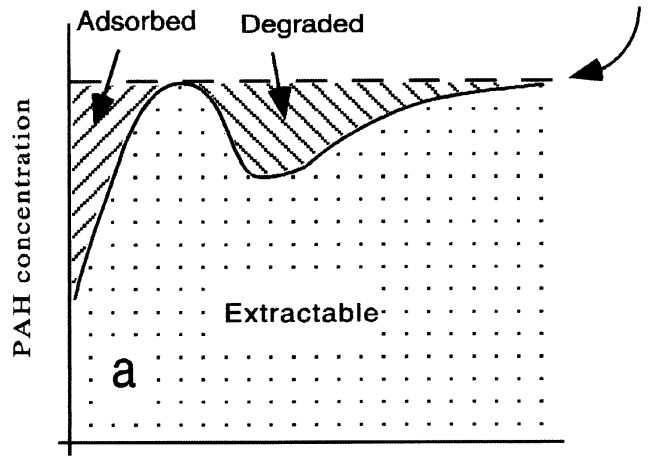

Distance from the root surface

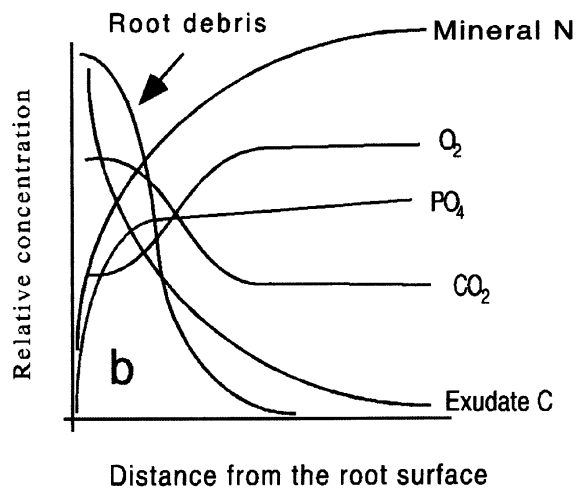

Figure 3. Schematic diagram of PAH dissipation in the rhizosphere (a), proposing a division of PAH dissipation into a non-extractable adsorbed fraction and degraded fraction. The zone of PAH adsorption corresponds to a zone where the root surface, root debris and root hairs are influential (b), and the zone of degradation corresponds to a zone where $\mathrm{O}_{2}$, mineral nutrients $(\mathrm{N}$ and $\mathrm{P})$ and root exudates are present in ample amounts.

\subsection{Mycorrhizal effects - plant growth}

Plant colonization by symbiotic soil microorganisms $\left(\mathrm{N}_{2}\right.$-fixing bacteria and mycorrhizal fungi) has obvious beneficial effects on host plant nutrition and physiology. One aspect of these effects is related to stress tolerance of plants, most commonly direct or indirect stress induced by nutrient deficiency. In the case of mycorrhiza, enhanced plant tolerance against other types of stress (toxic metals, salinity, drought, pathogens, etc.) is also a well-established phenomenon [24]. The role of mycorrhizas in metal-polluted soils has been investigated for more than two decades [6,39], but only recently has their corresponding role in organically polluted soils been addressed. The first reports on this aspect concerned mycorrhizal impact on plant establishment and growth on polluted soil. Here, improved toxicity tolerance may be difficult to distinguish from effects on improved plant nutrition, but results consistently indicate a favorable effect of mycorrhiza $[28,34,40,55]$.
Toxicity effects of organic pollutants on mycorrhizal fungi have also been described. The toxicity of single compounds in soil is usually limited, unless they are known to be acute toxins. Single PAHs, for example, do not always affect plant growth or mycorrhiza formation $[29,34,40,55]$, due to their low solubility and low acute toxicity. Some plant species do, however, seem more susceptible than others, e.g. clover more than ryegrass, and in the susceptible plant even AM colonization is affected [34]. PAHs, however, rarely occur as single pollutants in soil, but rather as a complex mixture of $>200$ different molecules. In concert, these may be additive with respect to toxicity and alter soil characteristics towards a hydrophobic matrix where water availability may pose additional constraints on aerobic biological activity such as root growth. Assessment of toxicity has thus commonly been made with complex pollution, either by diluting polluted environmental samples with non-polluted soil, or by adding a mixture of compounds to non-polluted soil. In one case where increased concentrations of crude oil $(0-50 \mathrm{~g} / \mathrm{kg})$ were added to a non-polluted soil, formation of arbuscular mycorrhizas was more sensitive than ectomycorrhizal formation [53]. The authors did, however, observe a change in dominant ectomycorrhizal morphotypes, and large differences between fungal species grown in pure culture at increasing hydrocarbon concentrations, indicating that ectomycorrhizal fungi differ widely in their tolerance towards organics. In contrast, Leyval and Binet [40] observed reduced growth of ryegrass, but no reduction in arbuscular mycorrhizal colonization using a single non-adapted fungus and ryegrass grown in soil amended with up to $5 \%$ of a heavily PAH-polluted soil $\left(8.1 \mathrm{~g}\right.$ PAHs $\left.\cdot \mathrm{kg}^{-1}\right)$.

\subsection{Mycorrhizal effects - degradation}

Few reports have addressed phytoremediation of organic pollutants as affected by mycorrhiza, in spite of repeated calls for such studies during the last decade [e.g. 2, 14]. Most of these concern ectomycorrhizal fungi in pure culture, rather than in symbiosis with plants. It has thus been demonstrated that ECM fungi may degrade several recalcitrant compounds such as 2,4-dichlorophenol [48], 2,4,6-trinitrotoluene [63], atrazine [17], polychlorinated biphenyls [18] and some 35 ring PAHs [7]. In a symbiotic state, with mycorrhiza-associated bacteria present, degradation capacities may be enhanced and extended to other compounds such as toluene and xylene $[16,62]$, though degradation rates may be influenced negatively when the pollutants are contained in soil or a soil-like material rather than in liquid media [48]. These rather diverse results concerning ectomycorrhizas are contrasted by a much lower number of reports on arbuscular mycorrhizas. A series of studies in our laboratory have focused on AM and its impact on degradation of PAHs. Starting out with spiking experiments and AM fungi with no history of contact with anthropogenically introduced PAHs (PAHs are also produced naturally during fire), we did not observe any differences in degradation of either anthracene (ANT) or a mixture of eight PAHs between soil planted with mycorrhizal or non-mycorrhizal ryegrass after a growth period of 40 days [5]. A longer experiment with the same AM fungus, but using a mixed ryegrass/clover sward, 
three of the former eight PAHs and sequential harvesting (56 and 112 days) did, however, show a positive effect of AM inoculation on degradation of two of the three PAHs [33]: initially-added ANT was degraded almost completely in all treatments (including unplanted soil) within the first harvest. The more recalcitrant compounds, chrysene (CHY) and dibenz[a,h]anthracene (DBA), disappeared faster in planted soil than in unplanted soil, but reached final concentrations that were similar, except for the mycorrhizal treatment that had lower concentrations for both CHY and DBA after 112 days (34 and 58\% of initially-added CHY and DBA remained in the mycorrhizal treatment, vs. 44 and $80 \%$, respectively, in both unplanted and planted treatments without AM).

Mechanistic explanations of arbuscular mycorrhizal effects on PAH degradation do not relate to fungal catabolism or cooxidation acting on the pollutant, as the involved fungi have very limited saprophytic capacities. Thus, we must seek explanations involving indirect effects of AM on the degradation activity of other rhizosphere microorganisms. Indeed, the time-course spiking experiment outlined above did demonstrate important qualitative differences in microbial community structure (based on phospholipid fatty acid analyses) of rhizosphere soil as affected by AM [33]. Differences in microbial community structure, assessed as bacterial carbon utilization patterns using Biolog plates, were also observed by Heinonsalo et al. [28] when comparing the rhizospheres of non-mycorrhizal and ectomycorrhizal treatments in an experiment with petroleum hydrocarbon-spiked soil. Enhanced degradation could in this case not be attributed to the ectomycorrhizal fungi or the associated bacteria, as they coexisted and could not be introduced individually. Both ectomycorrhizal fungi and their associated bacteria are able to degrade simple aromatic compounds [61]. Other mechanistic explanations include mycorrhizal effects on the activity of oxidative enzymes in roots and rhizosphere soil. Such enzymes are usually involved, e.g. in the initial ring cleavage of PAHs, and both peroxidase activity and co-factor concentrations (hydrogen peroxide) have been enhanced by arbuscular mycorrhizal root colonization $[13,60]$.

Spiking experiments have several advantages: one knows how much of each compound is added to the soil, and degradation metabolites are normally not present initially, so that degradation pathways may be deduced when these appear. Further, the added compounds have a high bioavailability, and toxicity effects on plants and soil organisms may be followed using an identical, non-spiked soil as a negative control. The corresponding disadvantages include the fact that recently introduced pollutants behave differently relative to aged ones, with large differences in bioavailability, and thus degradation rates and toxicity. Also, most bioremediation treatments will have an advantage if they exploit the indigenous microorganisms that have persisted after the pollution event, some of which would surely have the ability to attack the pollutant after long-term adaptation and selection. Finally, real polluted soils usually contain a wide range of recalcitrant compounds that must be dealt with simultaneously by any organism involved in bioremediating the soil. This complexity, and concurrent unfavorable soil characteristics (lack of proper soil structure, hydrophobicity, etc.) cannot be mimicked by spiking, and
Table I. Residual PAH concentrations in two industrially polluted soils as affected by the presence of plants, their growth period and mycorrhizal status (from [36]).

\begin{tabular}{|c|c|c|c|c|}
\hline \multirow{2}{*}{$\begin{array}{l}\text { Harvest } \\
\text { Treatment }\end{array}$} & \multirow{2}{*}{\multicolumn{2}{|c|}{$\begin{array}{c}\text { Soil 1 } \\
\Sigma 12 \mathrm{PAH} \\
\left(\mathrm{mg} \cdot \mathrm{kg}^{-1}\right)\end{array}$}} & \multirow{2}{*}{\multicolumn{2}{|c|}{$\begin{array}{c}\text { Soil } 2 \\
\Sigma 12 \mathrm{PAH} \\
\left(\mathrm{mg} \cdot \mathrm{kg}^{-1}\right)\end{array}$}} \\
\hline & & & & \\
\hline \multirow[t]{2}{*}{ Start } & 405 & $\mathrm{~b}$ & 2030 & $\mathrm{a}$ \\
\hline & & & & \\
\hline No plants & 348 & $\mathrm{c}$ & 1494 & $\mathrm{c}$ \\
\hline Non-myc. & 315 & $\mathrm{c}$ & 1577 & $\mathrm{bc}$ \\
\hline Myc. & 311 & $\mathrm{c}$ & 1539 & $\mathrm{bc}$ \\
\hline \multicolumn{5}{|l|}{26 weeks } \\
\hline No plants & 460 & $\mathrm{a}$ & 1763 & $\mathrm{~b}$ \\
\hline Non-myc. & 477 & $\mathrm{a}$ & 1382 & $\mathrm{c}$ \\
\hline Myc. & 435 & $a b$ & 1042 & $\mathrm{~d}$ \\
\hline
\end{tabular}

make it important to verify results obtained from spiking experiments by applying similar treatments to polluted soils.

Experimental evidence for the impact of mycorrhizas on degradation of organic pollutants using industrially polluted soils is scarce [49]. Enhanced degradation of non-polar petroleum hydrocarbons has been reported in treatments with mycorrhizal versus non-mycorrhizal pine [28], and mycorrhiza was assumed to play a role in the efficiency of TCE rhizodegradation in an experiment with Pinus taeda grown on soil from a solvent disposal site [3]. For arbuscular mycorrhiza, we are only aware of our own degradation studies using two PAHpolluted soils. Here we observed enhanced dissipation of several PAHs in a time-course experiment favored by mycorrhization of a mixed ryegrass-clover sward [36]. The least polluted $\left(400 \mathrm{mg} \mathrm{PAH} \cdot \mathrm{kg}^{-1}\right)$ and highly organic soil was proportionally less affected by mycorrhiza (but also by the presence of plants) than the severely polluted $\left(2000 \mathrm{mg} \mathrm{PAH} \cdot \mathrm{kg}^{-1}\right)$ soil, where the presence of AM led to an additional $20 \%$ reduction in PAH concentration (Tab. I). The same two soils grown with the same plants in the presence and absence of mycorrhiza and/or rhizobia did, however, not differ in residual PAH concentration in two experiments lasting up to 10 months (Joner, Johnson, McGrath and Leyval, unpublished results). The reasons for these contrasting results remain uncertain, but may be related to differences in mineral nutrient availability, pot sizes, magnitude of plant growth or other uncontrolled factors.

\subsection{Mycorrhizal extension of the rhizosphere}

Extraradical mycorrhizal hyphae are known as the roots of the roots, as they extend the sphere of root influence beyond the traditional rhizosphere, leading to e.g. nutrient depletion and enhanced activity of enzymes in soil further away from the roots than in non-mycorrhizal plants $[32,73]$. The question if this zone of influence (the 'hyphosphere', sensu [41]) may also be a privileged site for degradation of organic pollutants has so far not been addressed. The degradation potential in the 
hyphosphere is, however, significant, as hyphae allocate relatively significant amounts of carbon to this soil compartment [64], both as exuded glycoproteins and through subsequent hyphal decay. One may thus observe elevated microbial activity [76] and identify highly specific bacterial populations in this soil compartment [44] which may potentially enhance the degradation of organics.

\section{CONCLUSIONS}

The data available on mycorrhiza and degradation of organic pollutants are scarce. But when coupled with the wellknown effects of enhanced stress tolerance in plants harboring mycorrhizal endophytes, they become a strong incentive to include these symbioses in future experiments or in situ attempts on phytoremediation.

Considering mycorrhizas brings a complicating factor into the study of rhizosphere processes. When studying the rhizosphere, we are already placed, somewhat uncomfortably, across several areas of science as different as soil science, plant sciences, microbiology and chemistry. Adding 'symbiology' to this package may be asking too much. Commercially available inoculum is now commonly used in forestry and vegetation restoration, and the costs of mycorrhizal inoculation are no longer prohibitive. Also, new methodology for detection of both ectomycorrhizas $[4,21]$ and arbuscular mycorrhizas $[56,57]$ facilitates detection, identification and quantification of the involved fungi, so that spotting and characterizing mycorrhizas based on morphology (a knowhow that takes a long time to acquire) is no longer a necessity.

Phytoremediation is becoming a major application for rhizosphere technology. Still, we are only starting to learn about the detailed processes that take place in the rhizosphere, with even less knowledge existing for polluted soils where toxicity adds a complicating factor. Including mycorrhizas is another complicating consideration, but one that seems mandatory if rhizosphere technology should realize its potential in phytoremediation.

\section{REFERENCES}

[1] Abdelhafid R., Houot S., Barriuso E., How increasing availabilities of carbon and nitrogen affect atrazine behaviour in soils, Biol. Fertil. Soils 30 (2000) 333-340.

[2] Anderson T.A., Guthrie E.A., Walton B.T., Bioremediation in the rhizosphere: plant roots and associated microbes clean contaminated soil, Environ. Sci. Technol. 27 (1993) 2630-2636.

[3] Anderson T.A., Walton B.T., Comparative fate of $\left[{ }^{14} \mathrm{C}\right]$ trichloroethylene in the root zone of plants from a former solvent disposal site, Environ. Toxicol. Chem. 14 (1995) 2041-2047.

[4] Bååth E., Estimation of fungal growth rates in soil using ${ }^{14} \mathrm{C}$ acetate incorporation into ergosterol, Soil Biol. Biochem. 33 (2001) 2011-2018.

[5] Binet P., Portal J.M., Leyval C., Fate of polycyclic aromatic hydrocarbons $(\mathrm{PAH})$ in the rhizosphere and mycorrhizosphere of ryegrass, Plant and Soil 227 (2000) 207-213.

[6] Bradley R., Burt A., Read D., Mycorrhizal infection and resistance to heavy metal toxicity in Calluna vulgaris, Nature 292 (1981) $335-337$.
[7] Braun-Lüllemann A., Hüttermann A., Majcherczyk A., Screening of ectomycorrhizal fungi for degradation of polycyclic aromatic hydrocarbons, Appl. Microbiol. Biotechnol. 53 (1999) 127-132.

[8] Breedveld G.D., Karlsen D.A., Estimating the availability of polycyclic aromatic hydrocarbons for bioremediation of creosote contaminated soils, Appl. Microbiol. Biotechnol. 54 (2000) 255-261.

[9] Carmichael L.M., Pfaender F.K., The effect of inorganic and organic supplements on the microbial degradation of phenanthrene and pyrene in soils, Biodegradation 8 (1997) 1-13.

[10] Chaineau C.H., Morel J.L., Oudot J., Biodegradation of fuel oil hydrocarbons in the rhizosphere of maize, J. Environ. Qual. 29 (2000) 569-578.

[11] Chang Y.Y., Corapcioglu M.Y., Plant-enhanced subsurface bioremediation of nonvolatile hydrocarbons, J. Environ. Eng. ASCE 124 (1998) 162-169.

[12] Corgié S.C., Joner E.J., Leyval C., Spatial approach to phenanthrene degradation in the rhizosphere, Plant and Soil (2003) in press.

[13] Criquet S., Joner E.J., Léglize P., Leyval C., Anthracene and mycorrhiza affect the activity of oxidoreductases in the roots and the rhizosphere of lucerne (Medicago sativa L.), Biotechnol. Lett. 22 (2000) 1733-1737.

[14] Cunningham S.D., Anderson T., Schwab A.P., Hsu F.C., Phytoremediation of soils contaminated with organic pollutants, Adv. Agron. 56 (1996) 55-114.

[15] Curl E.A., Truelove B., The Rhizosphere, Springer Verlag, Berlin, $1986,288 \mathrm{p}$

[16] Dittmann J., Heyser W., Bucking H., Biodegradation of aromatic compounds by white rot and ectomycorrhizal fungal species and the accumulation of chlorinated benzoic acid in ectomycorrhizal pine seedlings, Chemosphere 49 (2002) 297-306.

[17] Donnelly P.K., Entry J.A., Crawford D.L., Degradation of atrazine and 2,4-dichlorophenoxyacetic acid by mycorrhizal fungi at three nitrogen concentrations in vitro, Appl. Environ. Microbiol. 59 (1993) 2642-2647.

[18] Donnelly P.K., Fletcher J.S., PCB metabolism by ectomycorrhizal fungi, Bull. Environ. Contam. Toxicol. 54 (1995) 507-513.

[19] Duineveld B.M., Rosado A.S., Van Elsas J.D., Van Veen J.A., Analysis of the dynamics of bacterial communities in the rhizosphere of the chrysanthemum via denaturing gradient gel electrophoresis and substrate utilization patterns, Appl. Environ. Microbiol. 64 (1998) 4950-4957.

[20] EPA, Introduction to phytoremediation, US Environmental Protection Agency, Cincinnati, 2000, 72 p.

[21] Erland S., Abundance of Tylospora fibrillosa ectomycorrhizas in a south Swedish spruce forest measured by RFLP analysis of the PCR-amplified rDNA ITS region, Mycol. Res. 99 (1995) 14251428.

[22] Fang C.W., Radosevich M., Fuhrmann J.J., Atrazine and phenanthrene degradation in grass rhizosphere soil, Soil Biol. Biochem. 33 (2001) 671-678.

[23] Flathman P.E., Lanza G.R., Phytoremediation: Current views on an emerging green technology, J. Soil Contam. 7 (1998) 415-432.

[24] Gianinazzi S., Schüepp H., Impact of arbuscular mycorrhizas on sustainable agriculture and natural ecosystems. Advances in Life Sciences, Birkhäuser Verlag, Basel, 1994, 226 p.

[25] Gramss G., Rudeschko O., Activities of oxidoreductase enzymes in tissue extracts and sterile root exudates of three crop plants, and some properties of the peroxidase component, New Phytol. 138 (1998) 401-409.

[26] Günther T., Dornberger U., Fritsche W., Effects of ryegrass on biodegradation of hydrocarbons in soil, Chemosphere 33 (1996) 203-215. 
[27] Hatzinger P.B., Alexander M., Effect of aging of chemicals in soil on their biodegradability and extractability, Environ. Sci. Technol. 29 (1995) 537-545.

[28] Heinonsalo J., Jorgensen K.S., Haahtela K., Sen R., Effects of Pinus sylvestris root growth and mycorrhizosphere development on bacterial carbon source utilization and hydrocarbon oxidation in forest and petroleum-contaminated soils, Can. J. Microbiol. 46 (2000) 451-464.

[29] Henner P., Schiavon M., Druelle V., Lichtfousse E., Phytotoxicity of ancient gaswork soils. Effect of polycyclic aromatic hydrocarbons (PAHs) on plant germination, Org. Geochem. 30 (1999) 963 969.

[30] Horvath R.S., Microbial co-metabolism and the degradation of organic compounds in nature, Bact. Rev. 36 (1972) 146-155.

[31] Hsu T.S., Bartha R., Accelerated mineralization of two organophosphate insecticides in the rhizosphere, Appl. Environ. Microbiol. 37 (1979) 36-41.

[32] Joner E.J., Magid J., Gahoonia T.S., Jakobsen I., P depletion and activity of phosphatases in the rhizosphere of mycorrhizal and non-mycorrhizal cucumber (Cucumis sativus L.), Soil Biol. Biochem. 27 (1995) 1145-1151.

[33] Joner E.J., Johansen A., dela Cruz M.A.T., Szolar O.J.H., Loibner A., Portal J.M., Leyval C., Rhizosphere effects on microbial community structure and dissipation and toxicity of polycyclic aromatic hydrocarbons (PAHs) in spiked soil, Environ. Sci. Technol. 35 (2001) 2773-2777.

[34] Joner E.J., Leyval C., Influence of arbuscular mycorrhiza on clover and ryegrass grown together in a soil spiked with polycyclic aromatic hydrocarbons, Mycorrhiza 10 (2001) 155-159.

[35] Joner E.J., Corgié S., Amellal N., Leyval C., Nutritional constraints to PAH degradation in a rhizosphere model, Soil Biol. Biochem. 34 (2002) 859-864.

[36] Joner E.J., Leyval C., Rhizosphere gradients of polycyclic aromatic hydrocarbon (PAH) dissipation in two industrial soils, and the impact of arbuscular mycorrhiza, Environ. Sci. Technol. (2003) in press.

[37] Jungk A., Claassen N., Availability of phosphate and potassium as the result of interactions between root and soil in the rhizosphere, Z. Pflanzenernähr. Bodenk. 14 (1986) 411-427.

[38] Kaye J.P., Hart S.C., Competition for nitrogen between plants and soil microorganisms, Trend Ecol. Evol. 12 (1997) 139-143.

[39] Leyval C., Turnau K., Haselwandter K., Effect of heavy metal pollution on mycorrhizal colonization and function: physiological, ecological and applied aspects, Mycorrhiza 7 (1997) 139-153.

[40] Leyval C., Binet P., Effect of polyaromatic hydrocarbons in soil on arbuscular mycorrhizal plants, J. Environ. Qual. 27 (1998) 402 407.

[41] Li X.L., George E., Marschner H., Phosphorus depletion and $\mathrm{pH}$ decrease at the root-soil and hyphae-soil interfaces of VA mycorrhizal white clover fertilized with ammonium, New Phytol. 119 (1991) 397-404.

[42] Lindstrom J.E., Prince R.C., Clark J.C., Grossman M.J., Yeager T.R., Braddock J.F., Brown E.J., Microbial populations and hydrocarbon biodegradation potentials in fertilized shoreline sediments affected by the T/V Exxon Valdez oil spill, Appl. Environ. Microbiol. 57 (1991) 2514-2522.

[43] MacNaughton S.J., Stephen J.R., Venosa A.D., Davis G.A., Chang Y.-J., White D.C., Microbial population changes during bioremediation of an experimental oil spill, Appl. Environ. Microbiol. 65 (1999) 3566-3574.

[44] Mansfeld-Giese K., Larsen J., Bødker L., Bacterial populations associated with mycelium of the arbuscular mycorrhizal fungus Glomus intraradices, FEMS Microbiol. Ecol. 41 (2002) 133-140.

[45] Margesin R., Zimmerbauer A., Schinner F., Monitoring of bioremediation by soil biological activities, Chemosphere 40 (2000) 339-346.
[46] Marschner B., Sorption of polycyclic aromatic hydrocarbons (PAH) and polychlorinated biphenyls (PCB) in soil, J. Plant Nutr. Soil Sci. 162 (1999) 1-14.

[47] Marschner P., Yang C.-H., Lieberei R., Crowley D.E., Soil and plant specific effects on bacterial community composition in the rhizosphere, Soil Biol. Biochem. 33 (2001) 1437-1445.

[48] Meharg A.A., Cairney J.W.G., Maguire N., Mineralization of 2,4dichlorophenol by ectomycorrhizal fungi in axenic culture and in symbiosis with pine, Chemosphere 34 (1997) 2495-2504.

[49] Meharg A.A., Cairney J.W.G., Ectomycorrhizas - extending the capacities of rhizosphere remediation?, Soil Biol. Biochem. 32 (2000) 1475-1484.

[50] Michelsen A., Schmidt I.K., Jonasson S., Quarmby C., Sleep D., Leaf ${ }^{15} \mathrm{~N}$ abundance of subarctic plants provides field evidence that ericoid, ectomycorrhizal and non- and arbuscular mycorrhizal species access different sources of soil nitrogen, Oecologia 105 (1996) 53-63.

[51] Michelsen A., Quarmby C., Sleep D., Jonasson S., Vascular plant $\mathrm{N}-15$ natural abundance in heath and forest tundra ecosystems is closely correlated with presence and type of mycorrhizal fungi in roots, Oecologia 115 (1998) 406-418.

[52] Nichols T.D., Wolf D.C., Rogers H.B., Beyrouty C.A., Reynolds C.M., Rhizosphere microbial populations in contaminated soils, Water, Air, Soil Pollut. 95 (1997) 165-178.

[53] Nicolotti G., Egli S., Soil contamination by crude oil: impact of the mycorrhizosphere and the revegetation potential of forest trees, Environ. Pollut. 99 (1998) 37-43.

[54] Nye P.H., Tinker P.B., Solute movement in the soil-root system, Blackwell Scientific Publishers, Oxford, 1977, 342 p.

[55] Olexa T.J., Gentry T.J., Hartel P.G., Wolf D.C., Fuhrmann J.J., Reynolds C.M., Mycorrhizal colonization and microbial community structure in the rhizosphere of annual ryegrass grown in pyrene-amended soils, Int. J. Phytoremed. 2 (2000) 213-231.

[56] Olsson P.A., Bååth E., Jakobsen I., Söderström B., The use of phospholipid and neutral lipid fatty acids to estimate biomass of arbuscular mycorrhizal fungi in soil, Mycol. Res. 99 (1995) 623-629.

[57] Olsson P.A., Thingstrup I., Jakobsen I., Bååth E., Estimation of the biomass of arbuscular mycorrhizal fungi in a linseed field, Soil Biol. Biochem. 31 (1999) 1879-1887.

[58] Pradhan S.P., Conrad J.R., Paterek J.R., Srivastava V.J., Potential of phytoremediation for treatment of PAHs in soil at MGP sites, J. Soil Contam. 7 (1998) 467-480.

[59] Reid B.J., Jones K.C., Semple K.T., Bioavailability of persistent organic pollutants in soils and sediments - a perspective on mechanisms, consequences and assessment, Environ. Pollut. 108 (2000) 103-112.

[60] Salzer P., Corbiere H., Boller T., Hydrogen peroxide accumulation in Medicago truncatula roots colonized by the arbuscular mycorrhiza-forming fungus Glomus intraradices, Planta 208 (1999) 319-325.

[61] Sarand I., Timonen S., Nurmiaho Lassila E.L., Koivula T., Haahtela K., Romantschuk M., Sen R., Microbial biofilms and catabolic plasmid harbouring degradative fluorescent pseudomonads in Scots pine mycorrhizospheres developed on petroleum contaminated soil, FEMS Microbiol. Ecol. 27 (1998) 115-126.

[62] Sarand I., Timonen S., Koivula T., Peltola R., Haahtela K., Sen R., Romantschuk M., Tolerance and biodegradation of $\mathrm{m}$-toluate by Scots pine, a mycorrhizal fungus and fluorescent pseudomonads individually and under associative conditions, J. Appl. Microbiol. 86 (1999) 817-826.

[63] Scheibner K., Hofrichter M., Herre A., Michels J., Fritsche W., Screening for fungi intensively mineralizing 2,4,6-trinitrotoluene, Appl. Microbiol. Biotechnol. 47 (1997) 452-457.

[64] Schreiner R.P., Bethlenfalvay G.J., Mycorrhizal interactions in sustainable agriculture, Crit. Rev. Biotechnol. 15 (1995) 271-285. 
[65] Schwab A.P., Banks M.K., Biologically mediated dissipation of polyaromatic hydrocarbons in the root zone, in: Anderson T.A., Coats J.R. (Eds.), Bioremediation through rhizosphere technology, American Chemical Society, Washington, 1994, pp. 132-141.

[66] Siciliano S.D., Germida J.J., Enhanced phytoremediation of chlorobenzoates in rhizosphere soil, Soil Biol. Biochem. 31 (1999) 299-305.

[67] Siciliano S.D., Greer C.W., Plant-bacterial combinations to phytoremediate soil contaminated with high concentrations of 2,4,6 trinitrotoluene, J. Environ. Qual. 29 (2000) 311-316.

[68] Smith S.E., Read D.J., Mycorrhizal symbiosis, Academic Press, San Diego, 1997, 605 p.

[69] Steer J., Harris J.A., Shifts in the microbial community in rhizosphere and non-rhizosphere soils during the growth of Agrostis stolonifera, Soil Biol. Biochem. 32 (2000) 869-878.

[70] Stucki G., Alexander M., Role of dissolution and solubility in biodegradation of aromatic compounds, Appl. Environ. Microbiol. 53 (1987) 292-297.

[71] Suominen L., Jussila M.M., Makelainen K., Romantschuk M., Lindstrom K., Evaluation of the Galega-Rhizobium galegae system for the bioremediation of oil-contaminated soil, Environ. Pollut. 107 (2000) 239-244.

[72] Swindoll C.M., Aelion C.M., Pfaender F.K., Influence of inorganic and organic nutrients on aerobic biodegradation and on the adaptation response of subsurface microbial communities, Appl. Environ. Microbiol. 54 (1988) 212-217.

[73] Tarafdar J.C., Marschner H., Phosphatase activity in the rhizosphere and hyphosphere of VA mycorrhizal wheat supplied with inorganic and organic phosphorus, Soil Biol. Biochem. 26 (1994) 387-395.

[74] Thompson I.P., Bailey M.J., Ellis R.J., Maguire N., Meharg A.A., Response of soil microbial communities to single and multiple doses of an organic pollutant, Soil Biol. Biochem. 31 (1999) 95-105.

[75] Thompson P.L., Ramer L.A., Schnoor J.L., Uptake and transformation of TNT by hybrid poplar trees, Environ. Sci. Technol. 32 (1998) 975-980.

[76] Van Aarle I.M., The ecophysiology of arbuscular mycorrhizal fungi: Phosphatase activity associated with extraradical and intraradical mycelium, Ph.D. Thesis, University of Lund, 2002, 126 p.

[77] Walworth J.L., Woolard C.R., Braddock J.F., Reynolds C.M., Enhancement and inhibition of soil petroleum biodegradation through the use of fertilizer nitrogen: An approach to determining optimum levels, J. Soil Contam. 6 (1997) 465-480.

[78] Wang J.G., Bakken L.R., Competition for nitrogen during mineralization of plant residues in soil: Microbial response to $\mathrm{C}$ and $\mathrm{N}$ availability, Soil Biol. Biochem. 29 (1997) 163-170. 